\title{
Hidden Floridian biodiversity: mitochondrial and nuclear gene trees reveal four cryptic species within the scorched mussel, Brachidontes exustus, species complex
}

\author{
T. LEE and D. Ó FOIGHIL \\ Museum of Zoology and Department of Ecology and Evolutionary Biology, University of Michigan, 1109 Geddes Avenue, Ann Arbor, \\ MI 48109-1079, USA
}

\begin{abstract}
The well-documented Floridian 'Gulf/Atlantic' marine genetic disjunction provides an influential example of vicariant cladogenesis along a continental coastline for major elements of a diverse nearshore fauna. We are engaged in a two-part study that aims to place this disjunction into a regional Caribbean Basin phylogenetic perspective using the scorched mussel Brachidontes exustus as an exemplar. Our first step, documented here, is to thoroughly characterize the genetic structure of Floridian scorched mussel populations using mitochondrial $(\mathrm{mt})$ and nuclear markers. Both sets of markers recovered the expected disjunction involving sister clades distributed on alternate flanks of peninsular Florida and lineage-specific $\mathrm{mt}$ molecular clocks placed its origin in the Pliocene. The two sister clades had distinct population genetic profiles and the Atlantic clade appears to have experienced an evolutionarily recent bottleneck, although plots of the relative estimates of $N$ through time are consistent with its local persistence through the last Ice Age Maximum. Our primary novel result, however, was the discovery that the Gulf/Atlantic disjunction represents but one of three cryptic, nested genetic discontinuities represented in Floridian scorched mussel populations. The most pronounced phylogenetic split distinguished the Gulf and Atlantic sister clades from two additional nested cryptic sister clades present in samples taken from the southern Florida tropical marine zone. Floridian populations of B. exustus are composed of four cryptic taxa, a result consistent with the hypothesis that the Gulf/Atlantic disjunction in this morphospecies is but one of multiple latent regional genetic breakpoints.
\end{abstract}

Keywords: Bivalvia, Caribbean, Carolinian, genetic disjunction, phylogeny, sibling species

Received 13 May 2004; revision received 3 August 2004; accepted 3 August 2004

\section{Introduction}

In recent decades, historical biogeography has greatly benefited from the application of phylogenetics to distributional datasets (Cracraft 1994). Vicariance biogeography has been the most influential outgrowth of this interaction and it is based on the premise that the history of geographical subdivision should be detectable in the phylogenies of lineages distributed among the currently fragmented areas (Croizat et al. 1974; Cunningham \& Collins 1994). In marine environments, however, the relative importance of vicariance events in shaping the genetic

Correspondence: Taehwan Lee, Fax: +1 734 7634080; E-mail: taehwanl@umich.edu structuring of populations is potentially obscured by the latent potential for long distance dispersal events (Palumbi 1992, 1994; Lessios et al. 1998, 1999; Ó Foighil et al. 1999), by the enormous geographical distributions attained by many taxa (Kohn \& Perron 1994; Benzie 1999), and by the prevalence of sibling species complexes (Knowlton 1993, 2000).

Phylogenetic analyses of comparative molecular datasets can help address these issues by placing the genetic structuring of marine taxa into an historical context (Grosberg \& Cunningham 2001). Important novel phylogeographical insights have been gained from recent molecular studies of diverse marine invertebrates and, among the most intriguing (from a vicariance perspective), are those cases where previously unsuspected faunal genetic discontinuities have been revealed (Avise 1994; Lavery et al. 1996; Borsa et al. 


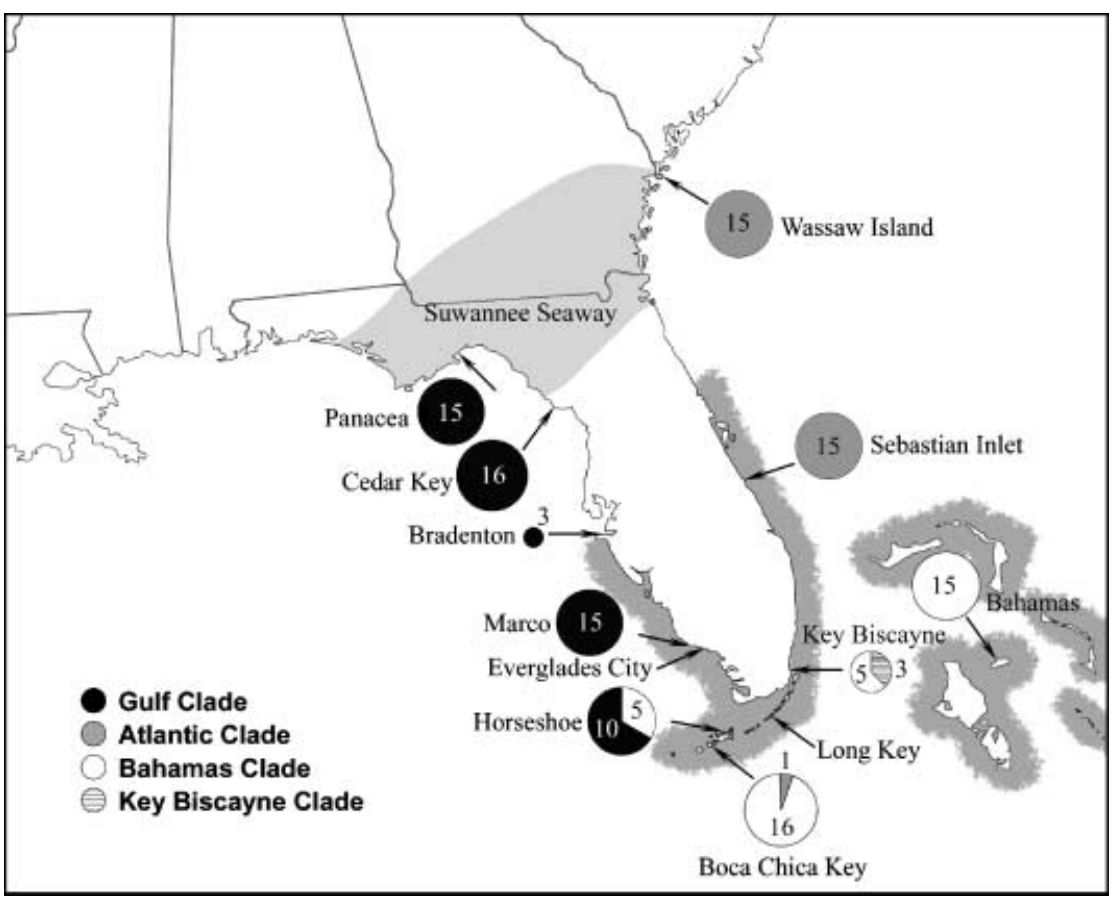

Fig. 1 Map of the Floridian peninsula (modified from Avise 2000) showing the approximate distribution of nearshore tropical marine fauna (tinted coastal area), the approximate position of the former Suwannee Strait, and the 12 sampling locations used in this study. A total of 134 specimens of Brachidontes exustus were genotyped for mitochondrial (mt) cytochrome $c$ oxidase subunit I from 10 of these locations (Wassaw Island, Sebastian Inlet, Bahamas, Key Biscayne, Boca Chica Key, Horseshoe, Marco, Bradenton, Cedar Key and Panacea). The accompanying pie charts indicate the number of individuals genotyped for each locality and their topological placement among the four primary $\mathrm{mt}$ clades recovered in this morphospecies (see Fig. 2 for clade identification).
1997; Chase et al. 1998; Williams \& Benzie 1998; Gopurenko et al. 1999). The marine fauna of peninsular Florida contains multiple congruent examples of such genetic break points (reviewed by Avise 1992, 2000; Cunningham \& Collins 1994; Palumbi 1994) and has played a central role in our understanding of how vicariance events can profoundly mould the genetic structuring of nearshore marine faunas in an ostensibly continuous coastal environment.

From a marine biogeographical perspective, peninsular Florida provides one of the most intriguing, and best studied, nearshore evolutionary landscapes. The southern section of the Floridian landmass projects into tropical marine waters, thereby isolating disjunct warm temperate water bodies on its north-eastern (Atlantic) and north-western (Gulf) flanks (Fig. 1). Approximate tropical/temperate transition points for these water bodies coincide with a significant turnover in morphologically distinguishable marine faunal elements and Briggs (1970, 1974), on the basis of faunistic similarity, grouped both Atlantic and Gulf warm temperate faunas into the Carolinian zoogeographical province. Many, but by no means all, Carolinian morphospecies presently have a distinctly allopatric distribution along the Floridian coastline (Avise 1992, 2000; Cunningham \& Collins 1994). Their last direct connection is thought to have been via the Suwannee Seaway, a former marine connection across the northern flank of the peninsula that existed during much of the Miocene and that may have persisted as late as the Pliocene (Bert 1986; Bert \& Harrison 1988; Webb 1990; Cunningham et al. 1991; Felder \& Staton 1994; Randazzo \& Jones 1997). The tropical marine faunal province has an asymmetric distribution in southern Florida, extending further north along the Atlantic coast (Fig. 1). This reflects the coastal embrace of a major oceanic current system. The powerful Florida Current section of the North Atlantic Gyre hugs the coast of south-eastern Florida as it exits the Gulf of Mexico and forms the tropical/temperate transition point for inshore water bodies where it veers offshore [normally near Cape Canaveral (Atkinson et al. 1983), approximately halfway up the peninsular Atlantic coast].

Replicate genetic characterizations of nominal species (including continuously distributed taxa) found on either flank of the Floridian peninsula have revealed cryptic phylogenetic disjunctions among diverse Gulf Atlantic Carolinian marine biotic elements (Avise 2000). Although some of the taxa studied showed no obvious genetic structuring along the peninsular coastline (Gold \& Richardson 1998; Avise 2000; Kirkendale et al. 2004), many yielded a Gulf Atlantic genetic disjunction in which genetic divergence levels among the two regional populations far surpassed that observed within either region (Avise 2000). Such disjunct patterns have been detected in a wide variety of nearshore species (Bert 1986; Saunders et al. 1986; Avise et al. 1987; Bert \& Harrison 1988; Cunningham et al. 1991; Sarver et al. 1992; Felder \& Staton 1994; Bert \& Arnold 1995; Duggins et al. 1995; Ó Foighil et al. 1996; Schizas et al. 1999; Avise 2000; Collin 2001, 2002; Gurgel et al. 2004), with by far the most intensively studied exemplar being the continuously distributed American oyster Crassostrea virginica (Reeb \& Avise 1990; Karl \& Avise 1992; Hare \& Avise 1996, 
1998; Hare et al. 1996; McDonald et al. 1996). The focal point of the regional genetic disjunction for these taxa generally occurs on the Atlantic coast and is often (Saunders et al. 1986; Reeb \& Avise 1990; Sarver et al. 1992), but not always (Bert 1986; Bert \& Harrison 1988; Schizas et al. 1999), centred on the Atlantic temperate tropical transition zone off east-central Florida.

The well-documented Gulf Atlantic genetic disjunction is important because it provides a clear example of vicariant cladogenesis along a continuous continental coastline for major elements of a diverse local fauna (Avise 2000). However, the general applicability of the Gulf Atlantic study system is limited because its findings have not been placed within a regional geographical and phylogenetic perspective. Does it represent a local anomaly which has no equivalent in, and little phylogenetic relevance to, other parts of the geographical range of regionally distributed morphospecies, or might it represent but one of a nested series of cryptic phylogenetic splits that underlay their assumed genetic cohesiveness?

The intertidal 'scorched' mussel, Brachidontes exustus, is nominally distributed southward from North Carolina, across the Gulf Atlantic disjunction, throughout the Caribbean Basin, and is also present on Bermuda (Abbott 1974; Sterrer 1986). This expansive regional range encompasses a continuous bicontinental coastline from North Carolina to Venezuela, in addition to a large number of islands, both continental (Greater and Lesser Antilles, Bahamas) and oceanic (Bermudan archipelago). It is also the product of a remarkably dynamic recent geological history that has profoundly reconfigured continental, oceanic, and archipelagean interfaces (Droxler et al. 1998; Iturralde-Vinent \& MacPhee 1999).

We are interested in establishing if a Gulf Atlantic genetic disjunction exists for B. exustus and, if so, revealing how it scales relative to the phylogenetic structuring experienced over the rest of its nominal collective range, including that of potentially geminate transisthmian Pacific sister taxa (Abbott 1974; Coan et al. 2000). The first step is to characterize thoroughly the genetic structure of Floridian populations using mitochondrial and nuclear markers. We do so here, and show that, although a well-defined Gulf Atlantic disjunction occurs, it involves only two of four cryptic Floridian taxa, implying that multiple additional genetic disjunctions may exist across the collective range of this regional morphospecies.

\section{Materials and methods}

\section{Samples}

A summary of sampling locations (see Fig. 1 for geographical placement) and of voucher specimen information is outlined in Table 1. Detailed sampling records have been deposited together with the voucher specimens in the Mollusc Collection of the University of Michigan's Museum of Zoology, Ann Arbor, MI, USA. All samples, apart from Long Key Brachidontes modiolus (the co-occurring congener

Table 1 Samples collected for this study with voucher specimen information (University of Michigan Museum of Zoology catalogue number)

\begin{tabular}{llc}
\hline Taxa & Locality & Catalogue number \\
\hline $\begin{array}{l}\text { Family Mytilidae } \\
\text { Brachidontes exustus }\end{array}$ & Panacea, FL, USA & 300111 \\
& Florida Marine Research Institute, Cedar Key, FL, USA & 300112 \\
& Rossi Waterfront Park, Bradenton, FL, USA & 300113 \\
& Marco, FL, USA & 300114 \\
& Boca Chica Key (oceanside), FL, USA & 300118 \\
& & 300120 \\
& Horseshoe (bayside, West Summerland Key), FL, USA & 300115 \\
& & 300121 \\
Cape Florida State Recreation Area, Key Biscayne, FL, USA & $300122-3$ \\
Sebastian Inlet State Park, Melbourne Beach, FL, USA & 300116 \\
Ischadium recurvum & Wassaw Island (oceanside), GA, USA & 300117 \\
& Delaport Point, New Providence, Bahamas & 300119 \\
Cape Florida State Recreation Area, Key Biscayne, FL, USA & 300124 \\
Geukensia granosissima & Long Key (oceanside), FL, USA & 300125 \\
Geukensia demissa & Gulf Specimen Marine Biological Supply, Panacea, FL, USA & 300126 \\
\hline & Florida Marine Research Institute, Cedar Key, FL, USA & 300127 \\
& Lostmans River Ranger Station, Everglades National Park, FL, USA & 300128 \\
& Rossi Waterfront Park, Bradenton, FL, USA & 300129 \\
& Marco, FL, USA & 300130 \\
& Wassaw Island (oceanside), GA, USA & 300131 \\
\hline
\end{tabular}


of B. exustus in southern Florida), were collected intertidally. Specimens were preserved in $95 \%$ ethanol prior to molecular characterization.

\section{Molecular data}

Standard DNA isolation methods were employed (detailed in Lee \& Ó Foighil 2003) to isolate genomic DNA from approximately $20 \mathrm{mg}$ tissue samples of individual specimens. Mytilids exhibit a remarkable doubly uniparental inheritance (DUI) system of sex-linked mitochondrial lineages in which males are heteroplasmic and paternally transmitted 'male' mitochondria become enriched in male germ line cells (Fisher \& Skibinski 1990; Hoeh et al. 1991; Geller 1994; Skibinski et al. 1994; Zouros et al. 1994; Rawson \& Hilbish 1995; Stewart et al. 1995; Quesada et al. 1996). Posterior adductor muscle tissue was targeted for DNA extraction because it was unlikely to be infiltrated by germline tissue and we therefore expected it to be dominated by maternally transmitted 'female' mitochondria irrespective of the gender of an individual mussel. In a minority of cases, where we wished to genotype the paternally transmitted mitochondrial ( $\mathrm{mt}$ ) lineage, we extracted DNA templates from fully developed male gonad tissue.

Four target gene fragments were amplified and directly sequenced from the study taxa. A 660 nucleotide (nt) portion of mt cytochrome $c$ oxidase subunit I (COI) was accessed via Folmer et al.'s (1994) widely used primer pair, LCO1490 and HCO2198. In addition, three discrete segments of the nuclear ribosomal gene cluster were sequenced. A $737 \mathrm{nt}$ (aligned length) fragment of the large nuclear subunit (28S) rDNA, encompassing domain 2 and part of domain 3, was characterized using primers D23F and D6R (Park \& Ó Foighil 2000). The nuclear ribosomal first internal spacer (ITS1, $611 \mathrm{nt}$ in aligned length) and second internal spacer (ITS2, $544 \mathrm{nt}$ in aligned length) were characterized using primers annealing to flanking regions of the $18 \mathrm{~S}$ and the 5.8S (White et al. 1996), and of the $5.8 \mathrm{~S}$ and the $28 \mathrm{~S}$ genes ( $\mathrm{Xu}$ et al. 2001), respectively. See Kirkendale et al. (2004), Park \& Ó Foighil (2000), Lee \& Ó Foighil (2003) and $\mathrm{Xu}$ et al. (2001) for details of polymerase chain reaction (PCR) conditions used to, respectively, amplify COI, 28S, ITS1 and ITS2 target gene fragments. A negative control (no template) was included in each amplification run. Double-stranded products were isolated on $1 \%$ agarose gels, excised under long-wavelength UV light, and extracted using a QIAquick gel extraction kit (Qiagen, Valencia, CA, USA). Both strands of the amplified fragments were directly cycle-sequenced, using the amplification primers, and the reaction products run, by the University of Michigan's Sequencing Core Facility. All novel DNA sequences have been deposited in the GenBank database (AY631835AY622009). The Geukensia demissa COI sequence was retrieved from the GenBank database (U56844).

\section{Phylogenetic analyses}

The COI sequences were aligned easily since there was an absence of indels. The nuclear ribosomal DNA fragments were aligned with CLUSTAL_x (Thompson et al. 1997) using default parameters and then adjusted by eye where necessary. A partition-homogeneity test (Farris et al. 1995) was performed (100 random replications) using PAUP* $4.0 \mathrm{~b} 10$ (Swofford 2003) to evaluate character congruence among 28S, ITS1 and ITS2 data sets.

Phylogenetic analyses were conducted on each of three datasets, presumptive female COI, female + male COI and combined nuclear ribosomal (28S + ITS1 + ITS2) datasets, using maximum parsimony (MP) as well as Bayesian methods. The MP analyses were performed with PAUP* using the heuristic search option [100 random stepwise additions and tree bisection-reconnection (TBR) branchswapping], and Geukensia and Ischadium species were designated as outgroup taxa (Distel 2000). Characters were unordered and equally weighted, and inferred sequence gaps were considered as missing data. Bootstrap (Felsenstein 1985) branch support levels were heuristically estimated with 100 replications, 10 random additions each. Because of the extensive computational time, the maximum number of trees to be saved was limited to 5000 and bootstrap values were accessed with the 'fast' stepwise-addition option for heuristic searches (10 000 replicates) when COI datasets were analysed.

Bayesian analyses were conducted using MRBAYEs 3.0b4 (Ronquist \& Huelsenbeck 2003). To determine the best-fit substitution model for each analysis, hierarchical likelihood ratio tests (hLRTs) were performed as implemented in Modeltest 3.06 (Posada \& Crandall 1998). The transversional model (Posada \& Crandall 2001) with invariant sites and gamma distribution (TVM $+\mathrm{I}+\Gamma)$ and Tamura \& Nei (1993) model with gamma distribution $(\operatorname{TrNef}+\Gamma)$ were, respectively, selected for the mt datasets (female COI and female + male COI) and the combined nuclear dataset (28S + ITS1 + ITS2). However, the TVM and TrNef models are special cases of the general time-reversible (GTR) model and are not yet implemented in MRBAYEs. Therefore, the GTR model (GTR $+\mathrm{I}+\Gamma$ for mt datasets and GTR + $\Gamma$ for nuclear dataset) was used in the analyses. Model parameter values were treated as unknown and were estimated for each analysis. While all nuclear genes were allowed to have their unique parameters, the COI third codon position was set up to have different gammadistributed rate variation $(\Gamma)$ and proportion of invariant sites (I) than the first and second position in the analyses of COI datasets. Random starting trees were used and analyses were run for one million generations, sampling every 100 generations for each dataset. Posterior clade probability values were estimated by generating a $50 \%$ majority rule consensus tree after the burn-in period of 2000 using PAUP*. 


\section{Within-clade genealogies}

Parsimony networks were constructed for major nominal B. exustus COI clades recovered using the statistical parsimony (Templeton et al. 1992) method in TCS version 1.13 (Clement et al. 2000). The network for each clade was compared with the topology of the maximum likelihood (ML) phylogeny to ensure concordance. The ML analyses were conducted on each dataset using the best-fit substitution model individually determined by hLRTs using MODELTEST. Heuristic searches were performed using PAUP* in which the parameter values under the best-fit model were fixed and a MP tree was used as a starting point for TBR branch swapping.

Genetic structure of each clade was characterized with the analysis of molecular variation (AMOva; Excoffier $e t$ al. 1992) test and a pairwise mismatch analysis based on simple pairwise distance. The single COI Atlantic clade haplotype obtained from Boca Chica Key was excluded from the AMOVA test to avoid a seriously biased estimate. To test for selective neutrality of $\mathrm{mt} \mathrm{COI}$ sequences, we implemented Tajima's (1989) $D$-test (10 000 permutations) for each clade. Haplotype diversity ( $H$; Nei 1987), nucleotide diversity ( $\pi$; the mean of pairwise sequence differences; Tajima 1983) and their sampling variances were also calculated for each clade. Haplotype and nucleotide diversities, Tajima's Dtest of neutrality, AMOVA, and mismatch distributions were estimated using ARLEQUIN 2.001 (Schneider et al. 2000).

\section{Estimation of sequence divergence rates and Gulf Atlantic divergence times}

We estimated the sequence divergence rates for our Brachidontes lineages using COI third codon positions. To account for ancestral within-lineage variations (Edward \& Beerli 2000), the net nucleotide divergence (Nei \& Li 1979) was calculated using ML-corrected pairwise sequence divergences among haplotypes belonging to transisthmian Panamian Brachidontes geminates (T. Lee \& D. Ó. Foighil, unpublished). Rates of sequence divergence were calibrated for a cessation of transisthmian gene flow at 3.6 million years (Myr) (Coates et al. 1992) and at 2.7 Myr (Marshall 1988). These calibration dates are likely to span the actual cessation of gene flow for intertidal Brachidontes because the former is based on the differentiation of nearshore mollusc palaeofaunas and the latter on the intercontinental exchange of land mammals. Likelihood ratio tests (Felsenstein 1981) were conducted on the COI third codon position dataset to test the rate consistency of a Poissondistributed molecular clock. These ML estimates were calculated using the HKY substitution model, which was chosen by hLRTs using MODELTEST. The relationship between sequence divergence and time since divergence was determined using a simple weighted linear regression and forcing the line through the origin (Hillis et al. 1996). This relationship was then used to estimate the divergence times of the Brachidontes Gulf Atlantic disjunction.

\section{Estimation of population parameters}

Ancestral population parameters, $\Theta(=2 N \mu$ for the mtDNA genome, where $N=$ the effective population size and $\mu=$ the mutation rate) and $g$ (the exponential growth rate of the population) were jointly calculated for the Gulf and Atlantic Brachidontes clades using Fluctuate 1.4 (Kuhner et al. 1998). Analyses were repeated 10 times for each clade using 10 short chains of 5000 steps each and five long chains of 25000 , with sampling increments of 20. UPGMA trees obtained using PAUP* for each clade were used as initial topologies. Each analysis used a ML-corrected transition: transversion ratio, estimated using PAUP* under the HKY substitution model. The COI third position divergence rates obtained above were converted into mutation rates per generation, assuming a Brachidontes generation time of 3 years (Morton 1988). These estimates were used to generate the relative effective population size at any time $t$ with the equation $N_{t}=\Theta \mathrm{e}-(g \mu) t$ (Kuhner et al. 1998).

\section{Results}

\section{Phylogeographical structure}

A total of 147 nominal B. exustus individuals, sampled from 10 regional sampling locations (Fig. 1), were characterized for the target $\mathrm{mt} \mathrm{COI}$ fragment and yielded 81 (presumptive female-lineage) haplotypes (Table 2). A subsample of 13 individuals, chosen to represent the primary COI tree topological features and the main sampling locations, were also genotyped for the target nuclear ribosomal fragments (28S, ITS1 and ITS2). Partition-homogeneity analysis of nuclear ribosomal datasets indicated that they were not significantly incongruent $(P=0.68)$ and we amalgamated them to perform combined phylogenetic analyses. Separate phylogenetic analyses of the B. exustus $\mathrm{mt}$ dataset, and of the concatenated nuclear dataset, were performed, together with those of the co-occurring congener B. modiolus, using regional Geukensia and Ischadium species as outgroups (Fig. 2). The mt and nuclear Bayesian analyses yielded congruent topologies, although mt tip clades were much better defined (Fig. 2). A monophyletic Brachidontes clade was recovered in which $B$. modiolus was sister to four nominal $B$. exustus clades. The latter resolved into two reciprocally monophyletic sets of sister taxa whose stem branches, in nuclear gene topologies, were markedly longer than those supporting terminal clades (Fig. 2). Not all nodes in the Bayesian topologies were recovered in the parsimony strict consensus trees: B. modiolus was weakly 
Table 2 Number of individuals sequenced (number of haplotypes) by cytochrome $c$ oxidase subunit I (COI) haplotype group and collection localities

\begin{tabular}{|c|c|c|c|c|c|c|c|c|c|c|c|c|c|c|}
\hline \multirow[b]{2}{*}{ COI haplotype group } & \multicolumn{12}{|c|}{ Number of individuals sequenced (number of haplotypes) by localities } & \multirow[b]{2}{*}{$n$} & \multirow[b]{2}{*}{$n h$} \\
\hline & PA & CK & $\mathrm{BR}$ & MA & EC & HS & $\mathrm{BC}$ & LK & $\mathrm{KB}$ & SI & WI & BA & & \\
\hline \multicolumn{15}{|l|}{ Brachidontes exustus } \\
\hline Gulf clade & $15(11)$ & $16(12)$ & $3(3)$ & $15(14)$ & & $10(6)$ & & & & & & & 59 & 39 \\
\hline Atlantic clade & & & & & & & $1(1)$ & & & $15(8)$ & $15(3)$ & & 31 & 10 \\
\hline \multicolumn{15}{|l|}{ Bahamas clade } \\
\hline $\mathrm{A}$ & & & & & & $4(4)$ & $11(9)$ & & $5(5)$ & & & $14(10)$ & 34 & 24 \\
\hline $\mathrm{B}$ & & & & & & $1(1)$ & $5(4)$ & & & & & $1(1)$ & 7 & 6 \\
\hline Male & & & & & & & $8(8)$ & & & & & $5(5)$ & 13 & 13 \\
\hline Key Biscayne clade & & & & & & & & & $3(2)$ & & & & 3 & 2 \\
\hline Brachidontes modiolus & & & & & & & & $2(2)$ & $1(1)$ & & & & 3 & 3 \\
\hline Ischadium recuroum & $6(6)$ & $3(2)$ & & & $1(1)$ & & & & & & & & 10 & 9 \\
\hline Geukensia granosissima & & & $4(4)$ & $2(2)$ & & & & & & & & & 6 & 6 \\
\hline Total & $21(17)$ & $19(14)$ & $7(7)$ & $17(16)$ & $1(1)$ & $15(11)$ & $25(22)$ & $2(2)$ & $9(8)$ & $15(8)$ & $16(4)$ & $20(16)$ & 166 & 99 \\
\hline
\end{tabular}

PA, Panacea; CK, Cedar Key; BR, Bradenton; MA, Marco; EC, Everglades City; HS, Horseshoe; BC, Boca Chica Key; LK, Long Key; KB, Key Biscayne; SI, Sebastian Inlet; WI, Wassaw Island; BA, Bahamas; $n$, number of individuals sequenced; $n h$, number of unique haplotypes.

sister to the Key Biscayne B. exustus clade in the COI mt MP tree and, in the nuclear rDNA MP tree, this species formed a polytomy with the two stem branches supporting the tip B. exustus clades.

Two of the four nominal B. exustus clades met the expected geographical (Briggs 1970, 1974) and phylogenetic (Avise 1992) characteristics of a regional Gulf Atlantic disjunction. They were exclusively recovered from the respective flanks of the Floridian Peninsula, although both also had at least some representation in the Florida Keys (Fig. 1; Table 2). In addition, they formed reciprocally monophyletic robust sister groups in both $\mathrm{mt}$ and nuclear gene trees (Fig. 2). We will refer to them as the Gulf and Atlantic clades.

To our surprise, we also encountered an additional pair of phylogenetically robust (for both $\mathrm{mt}$ and nuclear markers), cryptic nominal B. exustus sister taxa in samples taken from the tropical marine zone of southern Florida and the Bahamas. One of the tropical zone clades was relatively widespread and was recovered from all four of our Florida Keys Bahamas sampling locations. For convenience, it will be referred to here as the 'Bahamas' clade, as it was exclusively present in the Bahamian sample (Fig. 1; Table 2). The Bahamas clade contained a well-defined mt phylogenetic dichotomy: a common tip clade (A) which was predominant in all four sampling sites, and a rarer tip clade (B) which was present in three out of four sites and most abundant in the Florida Keys (Fig. 2; Table 2). A subsample of individuals from both Bahamas mt tip clades (A, B) were also genotyped for the nuclear rDNA target gene fragments and these nuclear markers did not exhibit reciprocal genetic structuring when analysed phylogenetically (Fig. 2). In contrast to the Bahamas clade, the sister tropical clade was much rarer, was encountered only in the Key Biscayne sample $(n=3)$, and will be referred to here as the Key Biscayne clade. This particular sampling location was atypical in that very few Brachidontes (total $n=9$, comprising two B. exustus clades, in addition to B. modiolus, Table 2) were recovered, after much effort, from under rocks where they occurred as small, scattered individuals among clumps of Isognomon. Unlike other sampling sites, individuals were not observed attached to exposed rock surfaces.

One unexpected topological detail of both $\mathrm{mt}$ and nuclear gene trees concerned the outgroup taxa. Surprisingly, the two Gulf Atlantic Geukensia species were paraphyletic and the Gulf taxon, Geukensia granosissima, was sister to our Gulf samples of Ischadium recurvum (Fig. 2; Table 2).

\section{Within-clade genetic diversity levels}

We obtained sufficient samples of mt genotypes from three of the four nominal exustus lineages (Gulf, $n=59$; Atlantic, $n=31$; Bahamas, $n=34$ ) to provide insights into their comparative genetic diversity levels (Table 3), although the Bahamas lineage is additionally considered after partitioning it into its constituent A and B tip clades (Table 3). The haplotype diversity $(H)$ and the average pairwise difference $(\pi)$ among haplotypes in the Atlantic clade were significantly lower than those of the Gulf and Bahamas clades. The Atlantic clade also exhibited the lowest level of among-population variation and, unlike the Gulf and Bahamas (tip clade A) clades, it did not show significant genetic subdivision. Although Bahamas tip clade B showed a slightly positive value without significance $(P=0.452)$, Tajima's $D$ was negative for all three primary clades. The 


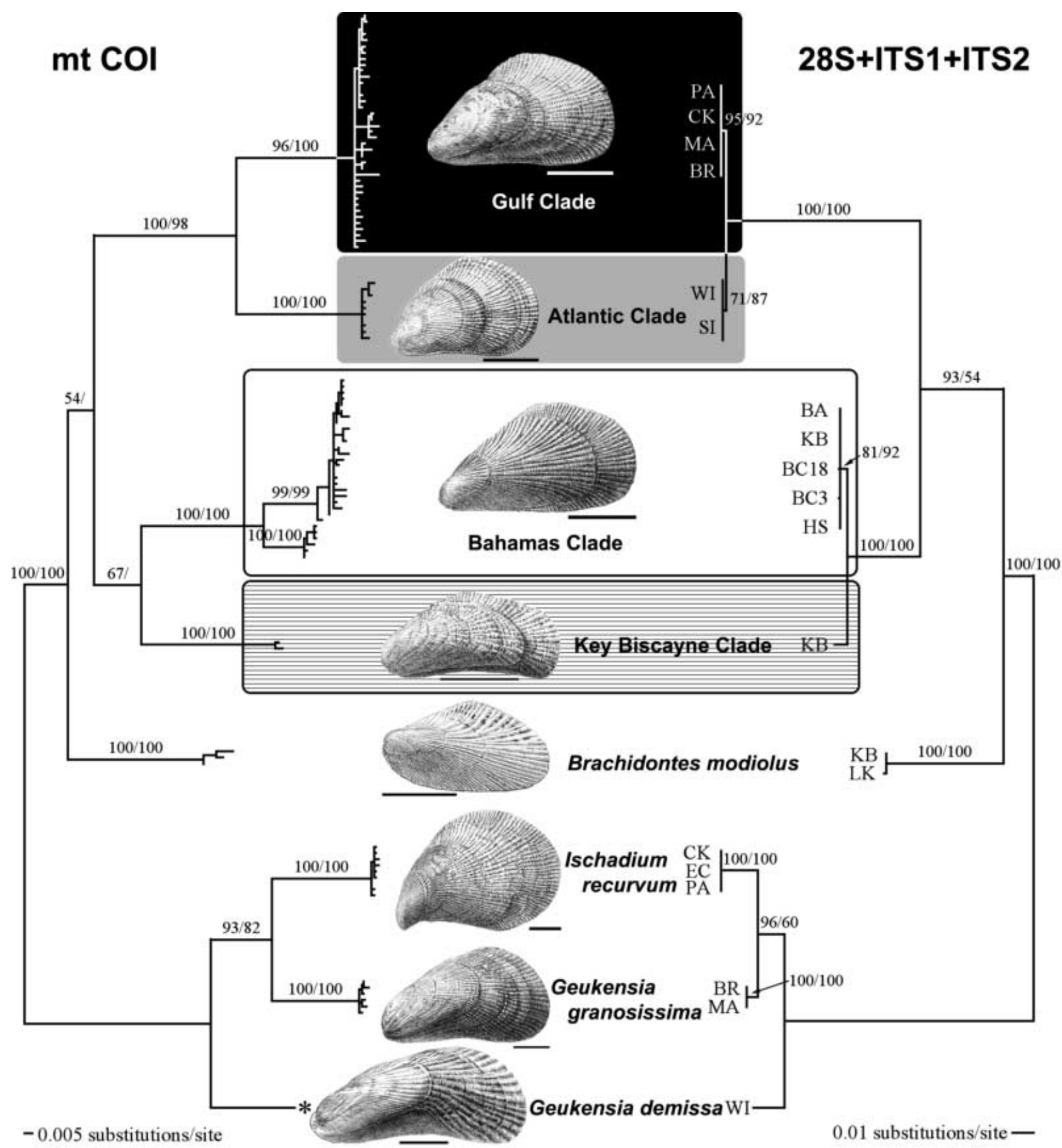

Fig. 2 Phylogenetic trees of Florida area Brachidontes obtained by Bayesian analyses of mitochondrial (mt) cytochrome $c$ oxidase subunit I (COI) (left) and combined (28S, ITS1 and ITS2) nuclear ribosomal (right) datasets using Ischadium and Geukensia spp. as outgroup taxa. Numbers above the branches represent the Bayesian posterior probabilities/parsimony bootstrap values for the supported nodes. Exemplar shell phenotypes are inserted for the four cryptic exustus taxa (plus Brachidontes modiolus and the three outgroup taxa) and their regional distributions can be visualized by referring to the correspondingly shaded pie charts in Fig. 1. Sampling locations of individuals typed for nuclear rDNA markers are indicated: BA, Bahamas; BC, Boca Chica Key; BR, Bradenton; EC, Everglades City; CK, Cedar Key; HS, Horseshoe; KB, Key Biscayne; LK, Long Key; MA, Marco; PA, Panacea; SI, Sebastian Inlet; WI, Wassaw Island. Scale bars represent $5 \mathrm{~mm}$, *We failed to amplify mt COI from our single available specimen of Geukensia demissa, sampled from Wassaw Island, and have included here a conspecific sequence from GenBank U56844. All other sequences represented in the tree topologies are de novo. 
Table 3 Haplotype $(H)$ and nucleotide diversity $(\pi)$, and estimates of Tajima's $D$-statistic and Amova test with associated level of significance calculated for the major mitochondrial cytochrome $c$ oxidase subunit I (COI) nominal Brachidontes exustus clades recovered

\begin{tabular}{|c|c|c|c|c|c|}
\hline $\begin{array}{l}\text { COI haplotype } \\
\text { groups }\end{array}$ & $\begin{array}{l}\text { Haplotype } \\
\text { diversity }(H)\end{array}$ & $\begin{array}{l}\text { Mean number of } \\
\text { pairwise differences }(\pi)\end{array}$ & Tajima's $D$ & $\begin{array}{l}\text { Variation among } \\
\text { populations (\%) }\end{array}$ & $\begin{array}{l}\text { Variation within } \\
\text { populations (\%) }\end{array}$ \\
\hline Gulf clade & $0.963 \pm 0.015$ & $5.425 \pm 2.651$ & $-1.809^{*}$ & $14.78^{*}$ & 85.22 \\
\hline Atlantic clade & $0.546 \pm 0.108$ & $1.312 \pm 0.841$ & $-2.074^{*}$ & 1.86 & 98.14 \\
\hline Bahamas clade & $0.981 \pm 0.011$ & $17.439 \pm 7.910$ & -0.286 & 5.11 & 94.89 \\
\hline Bahamas clade A & $0.973 \pm 0.014$ & $5.711 \pm 2.805$ & $-1.871^{*}$ & $9.58^{*}$ & 90.42 \\
\hline Bahamas clade B & $0.952 \pm 0.096$ & $4.762 \pm 2.647$ & 0.328 & 13.57 & 86.43 \\
\hline
\end{tabular}

${ }^{*} P<0.05$.

Table 4 Estimated ancestral population parameters $(\Theta=2 N \mu$ for the mtDNA genome, where $N=$ the effective population size and $\mu=$ the mutation rate per generation; $g$, the exponential growth rate of the population) for Gulf and Atlantic clades ( \pm SD). Estimates are based on ten replicate analyses of cytochrome $c$ oxidase subunit I (COI) third codon positions. The times at which the effective population size was $1 \%$ of its current size were calculated based on $g$ and $\mu$ [mutation rates per generation calibrated for a cessation of transisthmian gene flow at 3.6 million years (Coates et al. 1992) and at 2.7 million years (Marshall, 1988)]. 95\% confidence intervals are presented after each estimate

\begin{tabular}{|c|c|c|c|}
\hline COI Haplotype groups & $\Theta$ & $g$ & Time to $1 \%$ Relative $N$ \\
\hline Gulf clade & $0.4219 \pm 0.0708$ & $329.3 \pm 56.9$ & $\begin{array}{l}229376(207 \text { 182-256 896) } \\
172032 \text { (155 387-192 672) }\end{array}$ \\
\hline Atlantic clade & $0.0499 \pm 0.0139$ & $894.8 \pm 247.9$ & $\begin{array}{l}84423 \text { (72 052-101 922) } \\
63317 \text { (54 039-76 441) }\end{array}$ \\
\hline
\end{tabular}

$\Theta=2 N \mu$ for the mtDNA genome, where $N=$ the effective population size and $\mu$ = the mutation rate per generation; $g$, exponential growth rate of the population. Estimates are based on 10 replicate analyses of cytochrome $c$ oxidase subunit I (COI) third codon positions. The times at which the effective population size was $1 \%$ of its current size were calculated based on $g$ and $\mu$ [mutation rates per generation calibrated for a cessation of transisthmian gene flow at 3.6 million years (Coates et al. 1992) and at 2.7 million years (Marshall 1988)]. 95\% confidence intervals are presented after each estimate.

negative values were statistically significant for Gulf, Atlantic and Bahamas (tip clade A) clades, indicating an excess of rare haplotypes in these cases.

\section{Gulf Atlantic genealogical descriptions and estimates of population growth}

The contrasting mt diversity profiles of the exustus Gulf Atlantic sister taxa were placed in a historical perspective by generating unrooted gene networks (Fig. 3a,b) and pairwise mismatch distribution frequencies (Fig. 3c,d) for each clade. In relative terms, the Gulf network was topologically extensive, lacked a dominating mt genotype (most common of the 39 haplotypes occurred in 10 out of 59 individuals) and each sampling location contained multiple unique haplotypes (Fig. 3a). It produced a pairwise difference profile that peaked at four differences but was skewed to the right and a large fraction had $>6$ differences (Fig. 3c). In contrast, the Atlantic network (Fig. 3b) was numerically dominated $(21 / 31)$ by a single, centrally positioned haplotype, which was especially prominent (13/15 individuals) in the Wassaw Island sampling location (Figs 1 and 3b). The truncated Atlantic network topology was reflected in a pairwise differences profile that showed a unimodal decline from a peak at zero differences (Fig. 3d). Statistical parsimony analyses (Clement et al. 2000) identified the most common haplotype in each of the two Gulf/ Atlantic networks as the respective ancestral mt genotypes. However, the most common Gulf haplotype had an offcentre placement in its network (Fig. 3a) and was therefore a less compelling case than the presumptive ancestral Atlantic clade haplotype (Fig. 3b).

The relatively truncated Atlantic clade mt genealogical network (Fig. 3b) and pairwise difference profile (Fig. 3d) are consistent with a shallower coalescence time than that experienced by its sister Gulf clade. Extensive ongoing phylogenetic characterization of Caribbean and eastern Pacific Brachidontes populations has identified Panamian transisthmian sister lineages to the Gulf/Atlantic clade (Lee \& Ó Foighil unpublished) and allows us to apply lineagespecific molecular clocks to estimate ancestral demographic structure. Table 4 shows the parameters $\Theta$ and $g$ (the exponential growth rate of the population), calculated for the Gulf and Atlantic clades using fluctuATE (Kuhner et al. 1998), and the time to $1 \% \mathrm{~N}$ (relative to present-day estimates), for two clock calibrations. Plots of the relative estimates of $n$ through time for both clades are presented in Fig. 4. Note that for all rate calibrations (including 95\% confidence estimates), 
Gulf Clade
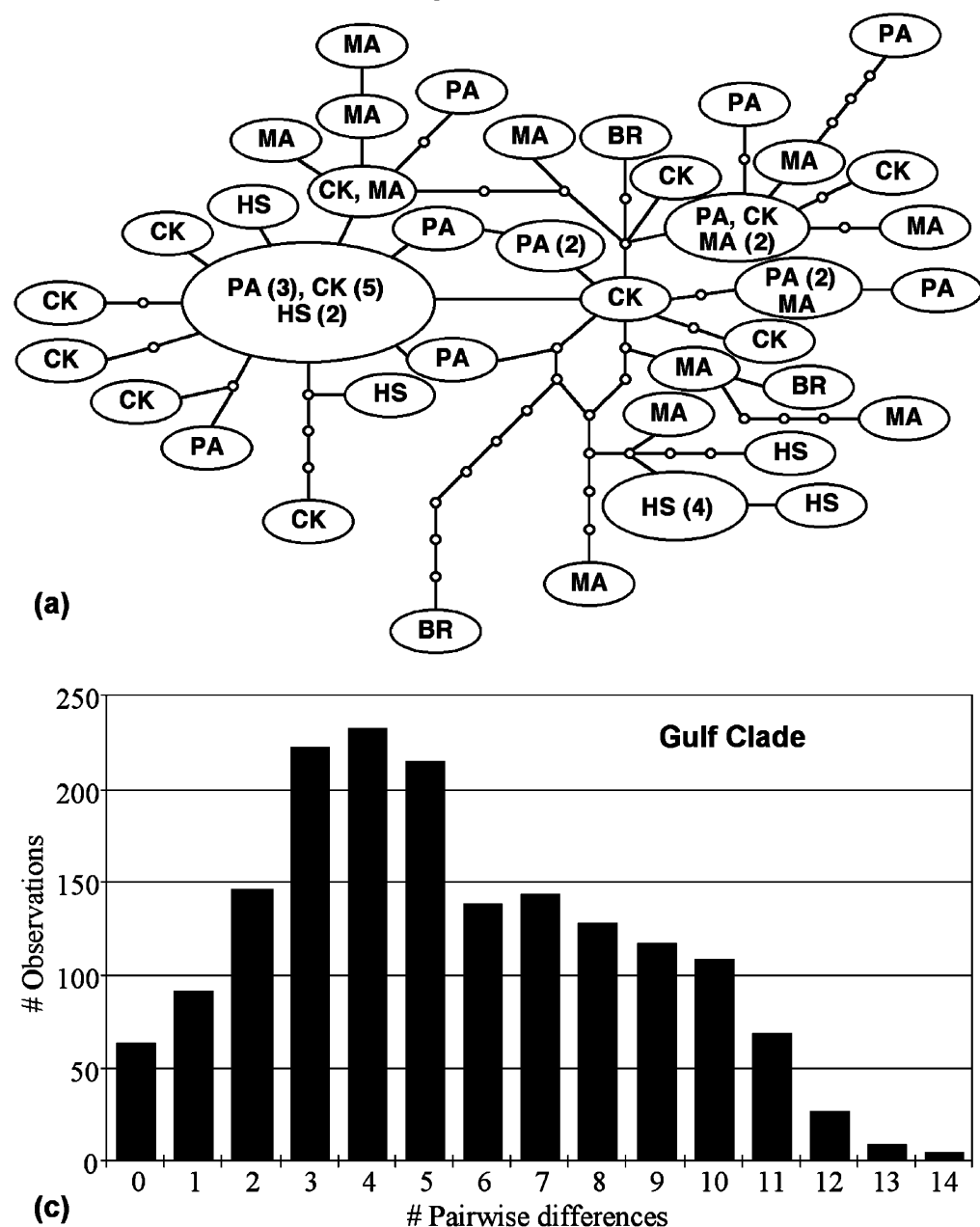

Atlantic Clade

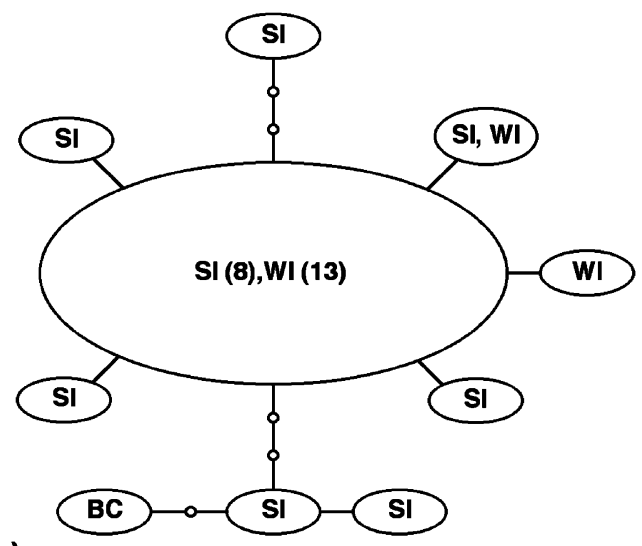

(b)

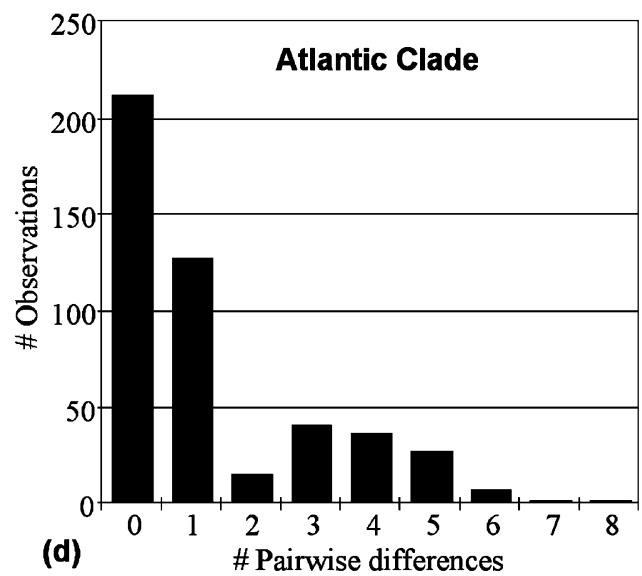

Fig. 3 (a) Statistical parsimony network of the 39 Brachidontes exustus Gulf of Mexico clade mitochondrial (mt) cytochrome $c$ oxidase subunit I (COI) haplotypes encountered in our study. The observed mt genotypes are represented by labelled ovals, their labels reflecting the sampling site(s) from which they were recovered: BR, Bradenton; CK, Cedar Key; HS, Horseshoe; MA, Marco; PA, Panacea; see Fig. 1 for map locations). The relative sizes of the labelled ovals reflects their relative abundance of each haplotype, e.g. 'PA' indicates a haplotype found in one individual sampled from the Panacea sample, whereas the most abundant haplotype 'PA (3), CK (5), HS (2)' was recovered from a total of 10 individuals obtained from three sampling sites (Panacea, Cedar Key and Horseshoe). Smaller unlabelled circles represent inferred 'missing' haplotypes. (b) Statistical parsimony network of the 10 B. exustus Atlantic clade mt COI haplotypes encountered in our study (BC, Boca Chica Key; SI, Sebastian Inlet; WI, Wassaw Island). Notation is as in (a). (b) Pairwise differences frequency distribution for the $39 \mathrm{mt}$ COI haplotypes obtained from 59 genotyped B. exustus Gulf of Mexico clade members. (d) Pairwise differences frequency distribution for the $10 \mathrm{mt}$ COI haplotypes obtained from 31 genotyped B. exustus Atlantic clade members.

the Atlantic clade experiences a significantly steeper decline to $1 \%$ of its present day estimated $N$ (54-102 000 years ago) than does the Gulf clade (155-257 000 years ago).

\section{Bahamas clade genealogical description}

Unlike its Gulf Atlantic nominal conspecifics, the Bahamas lineage exhibited a pronounced tip dichotomy in the $\mathrm{mt}$ gene tree topology - one that was not reflected in the nuclear gene tree (Fig. 2). Mytilid mitochondrial phylogenies can be complicated by 'resetting' of the DUI system (Hoeh et al. 1997; Quesada et al. 2003) and, to test for this possibility, we used male gonad tissue genomic extracts, from the two sampling sites dominated by the Bahamas clade (Fig. 1, Table 2), as templates for mt genotyping. Thirteen males were so genotyped and each mussel provided a unique haplotype (Table 2). When added to the COI dataset and analysed phylogenetically, the presumptive male-inherited (M) Bahamas genotypes formed a highly distinctive clade that was weakly nested within the exustus ingroup, but not sister to the presumptive female-inherited (F) Bahamas A and B mt tip clades (Fig. 5a). 


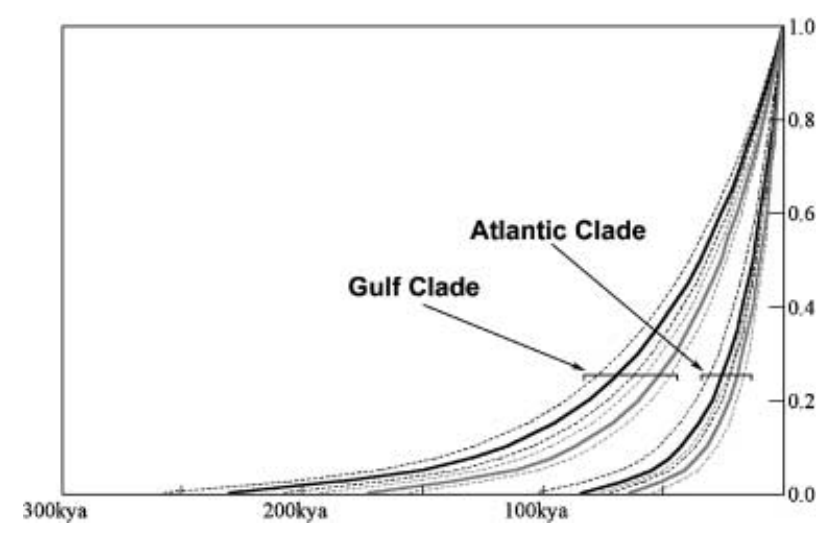

Fig. 4 Patterns of growth for Gulf and Atlantic clades of Brachidontes exustus based on estimates of the parameter $g$ (exponential growth rate of the population) generated jointly with $\Theta(=2 N \mu$ for the mtDNA genome, where $N=$ the effective population size and $\mu=$ the mutation rate) using FlUCtUATE (Kuhner et al. 1998). The $x$ axis represents time (thousand of years) and the $y$-axis represents the ancestral effective population sizes relative to current size. Two growth trajectories (with 95\% confidence intervals) are presented for each clade based on estimated molecular clock rates for Panamian Brachidontes transisthmian sister lineage mitochondrial (mt) cytochrome $c$ oxidase subunit I (COI) divergences (T. Lee and D. Ó Foighil unpublished), calibrated for a cessation of gene flow at 3.6 million years (Coates et al. 1992; black lines) and at 2.7 million years (Marshall 1988; grey lines).

When considered separately, the F Bahamas tip clades A and $B$ each produced a pairwise difference profile (Fig. 4b,c) that resembled (especially the much better-sampled $\mathrm{A}$ ) that of the Gulf clade (Fig. 3c) but not that of the Atlantic clade (Fig. 3d). When pairwise differences were plotted jointly for both F Bahamas clades A and B, a highly distinctive profile was produced characterized by two well-defined and markedly separated peaks (Fig. 4d). Interestingly, the M Bahamas mt clade also exhibited some tip definition (Fig. 4a) and its pairwise difference profile was also bimodal, although these peaks were less defined and less divergent than those of the F Bahamas mt genotypes (Fig. 4c).

\section{Discussion}

Our results show that the intertidal scorched mussel, $B$. exustus, represents another example of an ecologically prominent nearshore Floridian marine morphospecies that combines a continuous coastal distribution with cryptic phylogenetic structuring. However, the B. exustus species complex is qualitatively different from the typical pattern of a single genetic breakpoint observed in regional populations of, among others, Crassostrea (Reeb \& Avise 1990), Limulus (Saunders et al. 1986) and Geukensia (Sarver et al. 1992). Brachidontes exustus displays three nested phylogenetic splits, for both $\mathrm{mt}$ and nuclear genome markers, and Floridian populations are apparently composed of four cryptic intertidal species (Fig. 2). Remarkably, only one of the three observed genetic disjunctions fits the expected Gulf Atlantic distribution pattern (Figs 1 and 2), a result consistent with the hypothesis that the Gulf Atlantic disjunction in this morphospecies is but one of multiple latent regional genetic breakpoints.

\section{Carolinian Tropical disjunction}

In our gene trees (Fig. 2), the most pronounced of the three B. exustus phylogenetic splits distinguished the two Carolinian tip clades (Gulf and Atlantic) from the two Tropical tip clades (Bahamas and Key Biscayne). This feature was especially prominent in the nuclear rDNA tree topology where the stem branch lengths of the tip clade pairs greatly exceeded their terminal branches (Fig. 2), implying a much earlier Carolinian Tropical divergence. Although the Carolinian/Tropical clades were sister to each other (relative to the morphologically distinct regional congener B. modiolus) in the Bayesian topologies (Fig. 2), support levels were low for mt COI and parsimony analyses of both mt and nuclear markers failed to corroborate this exclusive sister relationship. Further phylogenetic characterization of Caribbean Basin populations is required to provide a fleshed-out perspective and emerging gene tree topologies from ongoing research (T. Lee \& D. Ó Foighil unpublished) have identified an exclusive Pacific sister lineage to the Gulf Atlantic clade, implying that the Carolinian Tropical split predates closure of the Isthmus of Panama. The generative Carolinian Tropical cladogenic event may therefore have occurred in a biogeographical context that was significantly different from present day conditions.

Southern Florida represents a presumed secondary contact zone for continuously distributed near-shore marine species exhibiting a Gulf Atlantic genetic disjunction (Avise 2000). A more complex scenario is apparent for B. exustus in which four phylogenetically well-defined clades overlapped in their south Florida distributions (Figs 1 and 2). Three of these clades appeared to have distinct geographical zones of ecological dominance: the Gulf Atlantic clades conforming to the primary regional pattern (Avise 2000) and the Bahamas clade prevailing in the tropical Bahamas and Florida Keys, with the exception of the Horseshoe sampling site where it was outnumbered by the Gulf clade (Fig. 1). The Florida Keys do not constitute a homogenous marine environment and there are marked habitat and faunal distinctions among inner (bayside) and outer (oceanside) Keys locations (Mikkelsen \& Bieler 2000). Such ecological factors may play a role in the relative abundance of Gulf and Bahamas B. exustus clades in the Horseshoe (bayside) and Boca Chica Key (oceanside) sampling sites (Fig. 1; Table 2). The other tropical B. exustus clade had an enigmatic distribution pattern and was recovered, in small numbers, only from the Key Biscayne sampling site (Fig. 1; 

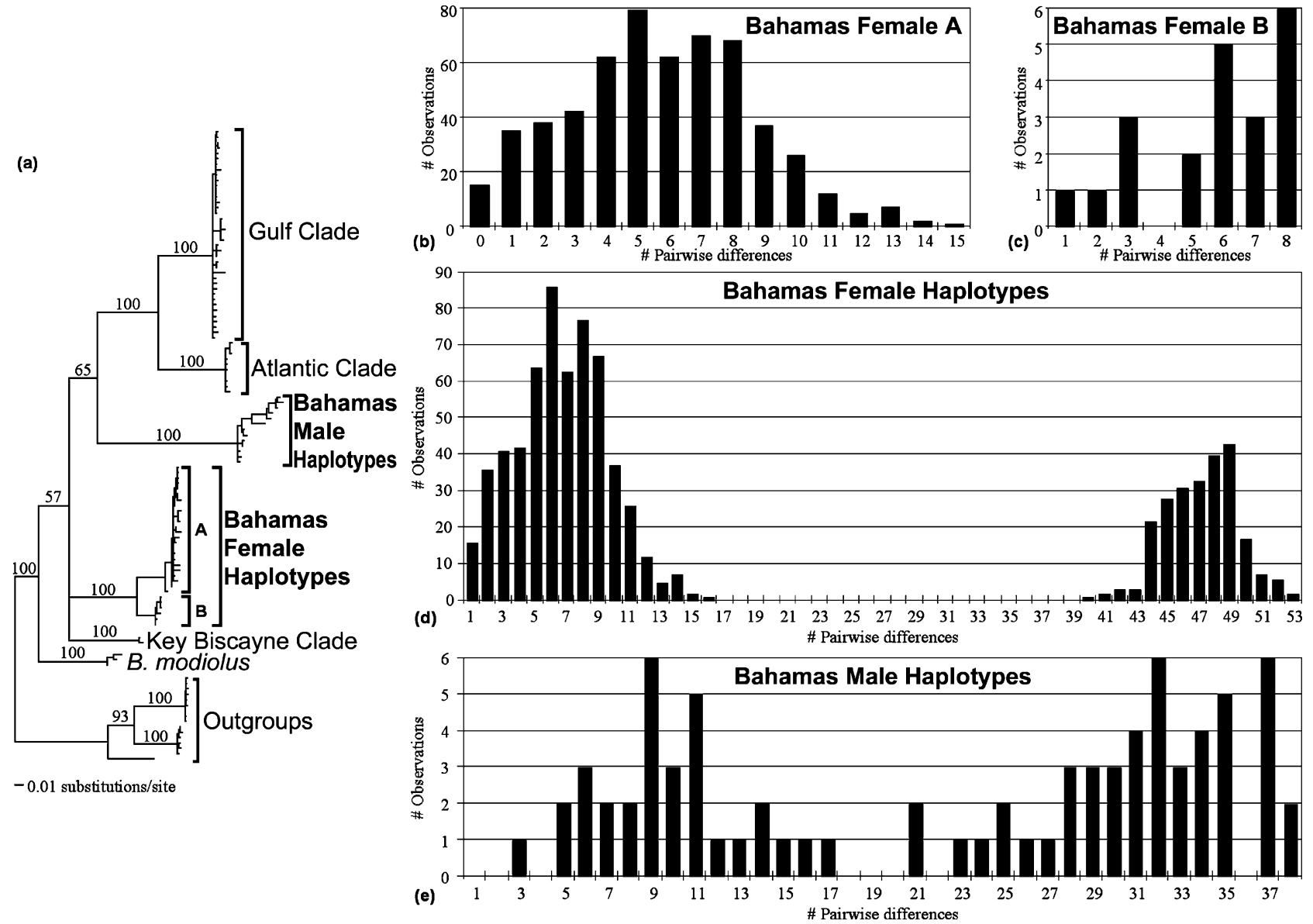

Fig. 5 (a) Bayesian phylogenetic tree of Florida area Brachidontes exustus mitochondrial (mt) cytochrome c oxidase subunit I (COI) genotypes that include 13 Bahamas clade putative male-inherited haplotypes (Table 2), in addition to 82 presumptive female-lineage haplotypes (Fig. 2; Table 2). Ischadium and Geukensia spp. were used as outgroup taxa and numbers above the branches represent the Bayesian posterior probabilities for the supported nodes. (b) Pairwise differences frequency distribution for the 24 presumptive female-lineage mt COI haplotypes obtained from 34 genotyped B. exustus Bahamas clade A members. (c) Pairwise differences frequency distribution for the six presumptive female-lineage $\mathrm{mt}$ COI haplotypes obtained from seven genotyped B. exustus Bahamas clade B members. (d) Pairwise differences frequency distribution for a combined B. exustus Bahamas clades A and B dataset of 30 presumptive female-lineage mt COI haplotypes obtained from 41 genotyped individuals. (e) Pairwise differences frequency distribution for 13 B. exustus Bahamas clades presumptive male-lineage mt COI haplotypes obtained from 13 genotyped individuals (Table 2).

Table 2) - an apparently marginal scorched mussel habitat. The Key Biscayne clade is clearly rare in Florida but may well have a more widespread, low frequency distribution there than our results indicate. One possibility is that the Key Biscayne individuals represent long-distance Florida Current-transported recruits from locally dominant, upstream source populations elsewhere in the Caribbean Basin, and preliminary results indicate that this clade may be common in the Antillean archipelago (T. Lee \& Ó. D. Foighil, unpublished).

\section{Gulf Atlantic disjunction}

Although the scorched mussel Gulf Atlantic phylogenetic disjunction complies biogeographically with the prevailing regional paradigm (Avise 2000), it exhibits a much higher level of molecular divergence for $\mathrm{mt}$ molecular markers $(\geq 12.7 \%$ for uncorrected $\mathrm{mt}$ COI) than do well-studied, continuously distributed taxa such as Limulus polyphemus (2\% divergence estimated by $\mathrm{mt}$ restriction fragment length polymorphism (RFLP) assays; Saunders et al. 1986) and C. virginica (2.5\% divergence estimated by $\mathrm{mt}$ RFLP assays; Reeb \& Avise 1990). This is graphically represented in Fig. 6 where corrected maximum likelihood networks are displayed for a homologous $\mathrm{mt} \mathrm{COI}$ fragment obtained from Gulf Atlantic B. exustus and C. virginica (Kirkendale et al. 2004) clades. This pronounced difference in network stem branch lengths for these two bivalve molluscs could result from a greater rate of molecular evolution, and/or a significantly older (but biogeographically congruent) 


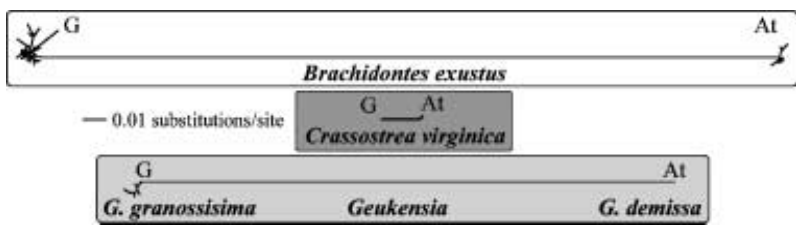

Fig. 6 Gulf Atlantic maximum likelihood networks for homologous mitochondrial $(\mathrm{mt})$ cytochrome $c$ oxidase subunit I (COI) gene fragments obtained from three bivalve molluscan taxa, Brachidontes $(-\ln =1172.8006$, HKY $85+\Gamma)$, Crassostrea $(-\ln =$ $-878.0842, \mathrm{HKY})$ and Geukensia $(-\ln =1196.1272, \mathrm{~K} 81 \mathrm{uf}+\Gamma)$. Brachidontes and Geukensia spp. sequences were generated as part of this study, except for the Geukensia demissa haplotype obtained from GenBank (U56844). The Crassostrea virginica network $(-\ln =$ 878.0842) is based on mt COI genotypes obtained from Panacea, Florida (Gulf) and from Skidaway River, Georgia (Atlantic) sampling locations (Kirkendale et al. 2004). Note that although the C. virginica COI fragment is approximately $10 \%$ shorter than that of the mussels (598 nt vs. $660 \mathrm{nt}$ ), it displays a proportionately much shallower (1.83\% uncorrected distance) Gulf Atlantic disjunction for $\mathrm{mt}$ COI (Kirkendale et al. 2004) than do Brachidontes $(\geq 12.7 \%)$ and Geukensia $(\geq 10.8 \%)$.

cladogenic event, in the scorched mussel. The latter situation is termed 'pseudocongruence' and has been invoked for the Gulf Atlantic regional disjunction as a possible explanation for the much more pronounced allozyme genetic distances observed for Geukensia relative to C. virginica (Cunningham \& Collins 1994), a feature also apparent in their respective Gulf Atlantic mt COI disjunctions (Fig. 6). Comparisons of degree of molecular divergence can of course be confounded by rate variation (Cunningham \& Collins 1994) and it is instructive to apply lineage-specific Brachidontes mt COI molecular clocks, calculated for third positions of transisthmian sister taxa (T. Lee \& D. Ó. Foighil unpublished), to the Gulf Atlantic data. Estimated rates of 18.29 and $24.38 \%$ /Myr were, respectively, calculated for a cessation of transisthmian gene flow at 3.6 Myr (Coates et al. 1992) and at 2.7 Myr (Marshall 1988), and yielded Gulf/Atlantic divergence times of 2.91-2.18 million years ago (Mya). The estimated mutation rates are unusually high, but it should be kept in mind that mytilid $\mathrm{mt}$ genomes exhibit high rates of mutation relative to those of other marine invertebrates (Wares \& Cunningham 2001) and that biogeographicalbased calibrations, such as we use here, tend to give inflated substitution rates relative to fossil record calibrations (Hillis et al. 1996; Marko 2002). Nevertheless, even if our transisthmian calibrated dates substantially underestimate the age of the Brachidontes Gulf Atlantic divergence, our Pliocene estimates are still much older than the 1.2 Mya Pleistocene suggested date of the Gulf Atlantic C. virginica disjunction (Reeb \& Avise 1990). Our results are therefore consistent with the hypothesis of pseudocongruence (Cunningham \& Collins 1994), although it should be kept in mind that the oyster estimate was based on a 'conventional' mt clock (Reeb \& Avise 1990).

One of the most striking features of the Brachidontes dataset is the contrasting $\mathrm{mt}$ genetic diversity profiles displayed by Atlantic and Gulf clades (Table 3, Fig. 3). Because both clades yield very similar Tajima's $D$-values (Table 3), their distinct mt population genetic profiles do not appear to have been shaped differentially by selection and the data are consistent with an evolutionarily recent population bottleneck specifically affecting the Atlantic clade. A broadly similar pattern (truncated diversity in the Atlantic clade) has been observed in Limulus (Saunders et al. 1986) and, to a lesser extent, in Crassostrea (Reeb \& Avise 1990), although for the latter, both Gulf and Atlantic populations were dominated by single, centrally positioned (Beckenbach 1994) haplotypes. Pleistocene glaciation cycles profoundly impacted the latitudinal distribution of northwestern Atlantic species, pushing their distributions to the south during glacial maxima (Cronin 1988; Pielou 1991; Wares 2002). It is likely that the present day FloridaNorth Carolina distribution of this clade was displaced southwards 20000 years ago at the end of the last glacial maximum (Williams et al. 1998). However, our estimates of $N$ through time for the Atlantic clade yield evidence of populations extending well prior to this date (Fig. 4), despite using potentially inflated biogeographical-based mutation rate calibrations (Hillis et al. 1996; Marko 2002). These estimates of evolutionary persistence of course assume that the observed Atlantic clade genotypes originated in situ. This assumption may have to be modified because an extensive ongoing genotyping of Caribbean nominal B. exustus populations is beginning to recover members of this clade in the southern Caribbean (T. Lee and D. Ó. Foighil unpublished). It remains to be established what impact these emerging genotypes will have on our estimates of the evolutionary persistence of this clade on the Atlantic coast of North America.

\section{Bahamas clade}

The Bahamas clade produced a distinctive mt population genetic profile composed of reciprocally monophyletic tip clades that, although present in unequal frequencies, did not display geographical exclusivity in our samples (Fig. 2; Table 2). Various evolutionary processes have been proposed to account for the coexistence of divergent mitochondrial clades within natural populations. These include the possibility that the polymorphism results from: (i) doubly uniparental inheritance of mitochondria (Hoeh et al. 1997; Quesada et al. 2003); (ii) the presence of cryptic species; (iii) retention of ancestral polymorphisms; (4) secondary contact between genetically distinct populations. Available data are inconsistent with the first two possibilities: presumptive male-inherited mt COI Bahamas 
genotypes represent a distinct, highly divergent clade (Fig. 5a) and the nuclear markers provide no evidence for the presence of a cryptic species (Fig. 2). We cannot distinguish among the last two possibilities at present, however, it may be possible to do so once the Bahamas clade is genetically characterized over its full geographical range (which remains to be established). Long-term persistence of ancestral population polymorphisms should result in the presence of highly divergent clades throughout a species' geographical range and the occurrence of many lineages of intermediate levels of divergence (Neigel \& Avise 1986). Conversely, mitochondrial introgression in a region of secondary contact should lead to the cooccurrence of divergent haplotypes within limited subsections of a taxon's geographical range and to the absence of intermediate haplotypes (Avise et al. 1987).

Our limited sampling of presumptive male-inherited (M) Bahamas Brachidontes mt COI lineages also exhibited a bimodal pattern of genotypic diversity (Fig. 5e), indicating (unsurprisingly) that they share a parallel population genetic history to that of the co-occurring, bimodal presumptive female-inherited (F) lineages (Fig. 5d). Comparison of the pairwise difference profiles among $\mathrm{F}$ (Fig. $5 \mathrm{~d}$ ) and among $\mathrm{M}$ (Fig. 5e) mt COI genotypes showed that observed $\mathrm{M}$ divergence levels were lower. Although based on a very preliminary $\mathrm{M}$ dataset, this result is the reverse of other studied bivalve mollusc DUI systems in which the M lineages typically exhibit significantly greater genetic divergence levels (Rawson \& Hilbish 1995; Stewart et al. 1995; Liu et al. 1996; Quesada et al. 1996; Skibinski et al. 1999; Passamonti et al. 2003), although not necessarily for all mt genes (Passamonti et al. 2003). A more comprehensive sampling of the $\mathrm{M}$ lineage from the Bahamas, and from sister Brachidontes lineages, together with complimentary $\mathrm{F}$ lineage data are required to meaningfully test relative $\mathrm{M}$ and $\mathrm{F}$ mt genome mutation rates in Brachidontes.

In summary, our scorched mussel data show that the expected Gulf Atlantic genetic discontinuity represents but one of three such cryptic disjunctions present in continuously distributed Floridian populations. These results are consistent with the hypothesis that the Gulf Atlantic split represents one example of multiple latent genetic breakpoints that exist across the collective range of this Caribbean Basin morphospecies. Ongoing phylogenetic characterization of Caribbean Basin populations and eastern Pacific putative geminates (T. Lee \& D. Ó. Foighil unpublished) aims to provide a broader geographical and historical context for the observed Floridian diversity by placing these four lineages into a Basin-wide evolutionary context.

\section{Acknowledgements}

We are grateful to two anonymous reviewers for their constructive input and to the following colleagues for providing sampling assistance: R. Bieler, R. Collin, T. Collins, P. Mikkelsen, T. J. Smith, R. Walker, R. Willan and K. Whelan. J. Megahan kindly drew the shell outlines used in Fig. 2. Supported by NSF award OCE0099084 to DÓF.

\section{References}

Abbott RT (1974) American Seashells. Van Nostrand Reinhold, New York, NY.

Atkinson LP, Lee TN, Blanton JO, Chandler WS (1983) Climatology of the southeastern United States continental shelf waters. Journal of Geophysical Research, 88, 4705-4718.

Avise JC (1992) Molecular population structure and the biogeographic history of a regional fauna: a case history with lessons for conservation biology. Oikos, 63, 62-76.

Avise JC (1994) Molecular Markers, Natural History and Evolution. Chapman \& Hall, New York, NY.

Avise JC (2000) Phylogeography. The History and Formation of Species. Harvard University Press, Cambridge, MA.

Avise JC, Reeb CA, Saunders NC (1987) Geographic population structure and species differences in mitochondrial DNA of mouthbrooding marine catfishes (Ariidae) and demersal spawning toadfishes (Batrachoididae). Evolution, 41, 991-1002.

Beckenbach AT (1994) Mitochondrial haplotype frequencies in oysters: neutral alternatives to selection models. In: Non-Neutral Evolution: Theories and Molecular Data (ed. Golding B), pp. 188 198. Chapman \& Hall, New York, NY.

Benzie JAH (1999) Genetic structure of coral reef organisms: ghosts of dispersal past. American Zoologist, 39, 131-145.

Bert TM (1986) Speciation in western Atlantic stone crabs (genus Menippe): the role of geological processes and climatic events in the formation and distribution of species. Marine Biology, 93, 157-170.

Bert TM, Arnold WS (1995) An empirical test of predictions of two competing models for the maintenance and fate of hybrid zones: both models are supported in a hard clam hybrid zone. Evolution, 49, 276-289.

Bert TM, Harrison RG (1988) Hybridization in western Atlantic stone crabs (genus Menippe): evolutionary history and ecological context influence species interactions. Evolution, 42, 528-544.

Borsa P, Naciri M, Bahiri L et al. (1997) Infraspecific zoogeography of the Mediterranean: population genetic analysis on sixteen Atlanto-Mediterranean species (fishes and invertebrates). Vie Milieu, 47, 295-305.

Briggs JC (1970) A faunal history of the North Atlantic Ocean. Systematic Zoology, 19, 19-34.

Briggs JC (1974) Marine Zoogeography. McGraw-Hill, New York, NY.

Chase MR, Etter RJ, Rex MA, Quattro JM (1998) Bathymetric patterns of genetic variation in a deep-sea protobranch bivalve, Demninucula atacellana. Marine Biology, 131, 301-308.

Clement M, Posada D, Crandall KA (2000) тcs: a computer program to estimate gene genealogies. Molecular Ecology, 9, 1657-1660.

Coan EV, Scott PV, Bernard FR (2000) Bivalve Seashells of North America. Santa Barbara Museum of Natural History, Santa Barbara, CA.

Coates AG, Jackson JBC, Collins LS et al. (1992) Closure of the Isthmus of Panama: the near-shore marine record of Costa Rica and western Panama. Geological Society of America Bulletin, 104, 814-828. 
Collin R (2001) The effects of mode of development on phylogeography and population structure of North Atlantic Crepidula (Gastropoda: Calyptraeidae). Molecular Ecology, 10, 2249-2262.

Collin R (2002) Another last word on Crepidula convexa with a description of C. ustulatulina n. sp. (Gastropoda: Calyptraeidae) from the Gulf of Mexico and southern Florida. Bulletin of Marine Science, 70, 177-184.

Cracraft J (1994) Species diversity, biogeography and the evolution of biotas. American Zoologist, 34, 33-47.

Croizat L, Nelson G, Rosen DE (1974) Centers of origin and related concepts. Systematic Zoology, 23, 265-287.

Cronin TM (1988) Evolution of marine climates of the US Atlantic coast during the past four million years. Philosophical Transactions of the Royal Society of London B, 318, 661-678.

Cunningham CW, Collins TM (1994) Developing model systems for molecular biogeography: vicariance and interchange in marine invertebrates. In: Molecular Ecology and Evolution: Approaches and Applications (eds Schierwater B, Streit B, Wagner GP, DeSalle R), pp. 405-433. Birkhauser Verlag Basel, Basel.

Cunningham CW, Buss LW, Anderson CW (1991) Molecular and geological evidence of shared history between hermit crabs and the symbiotic genus Hydractinia. Evolution, 458, 1301-1316.

Distel DL (2000) Phylogenetic relationships among Mytilidae (Bivalvia): 18S rRNA data suggest convergence in mytilid body plans. Molecular Phylogenetics and Evolution, 15, 25-33.

Droxler AW, Burke K, Cunningham AD et al. (1998) Caribbean constraints on circulation between Atlantic and Pacific oceans over the past 40 million years. In: Tectonic Boundary Conditions for Climate Reconstruction (eds Crowley T, Burke K), pp. 160-191. Oxford University Press, Oxford.

Duggins CF, Karlin AA, Mousseau TA, Relyea KG (1995) Analysis of a hybrid zone in Fundulus majalis in a northeastern Florida ecotone. Heredity, 74, 117-128.

Edwards S, Beerli P (2000) Gene divergence, population divergence, and the variance in coalescence time in phylogeographic studies. Evolution, 54, 1839-1854.

Excoffier L, Smouse PE, Quattro JM (1992) Analysis of molecular variance inferred from metric distances among DNA haplotypes: application to human mitochondrial DNA restriction data. Genetics, 131, 45479-45491.

Farris JS, Källersjö M, Kluge AG, Bult C (1995) Testing significance of congruence. Cladistics, 10, 315-319.

Felder DL, Staton JL (1994) Genetic differentiation in the GulfAtlantic species complexes of Sesarma and Uca (Crustacea: Decapoda: Brachyura). Journal of Crustacean Biology, 14, 191-209.

Felsenstein J (1981) Evolutionary trees from DNA sequences: a maximum likelihood approach. Journal of Molecular Evolution, $32,79-81$.

Felsenstein J (1985) Confidence limits on phylogenies: an approach using the bootstrap. Evolution, 39, 783-791.

Fisher C, Skibinski DOF (1990) Sex-biased mitochondrial DNA heteroplasmy in the marine mussel Mytilus. Proceedings of the Royal Society London Series B, 242, 149-156.

Ó Foighil D, Hilbish TJ, Showman RM (1996) Mitochondrial gene variation in Mercenaria clam sibling species reveals a relict secondary contact zone in the western Gulf of Mexico. Marine Biology, 126, 675-683.

Ó Foighil D, Marshall BA, Hilbish TJ, Pino MA (1999) TransPacific range extension by rafting is inferred for the flat oyster Ostrea chilensis. Biology Bulletin, 196, 122-126.

Folmer O, Black M, Hoeh W, Lutz R, Vrijenhork R (1994) DNA primers for amplification of mitochondrial cytochrome $c$ oxidase subunit I from diverse metazoan invertebrates. Molecular Marine Biology and Biotechnology, 3, 294-299.

Geller JB (1994) Sex-specific mitochondrial DNA haplotypes and heteroplasmy in Mytilus trossulus and Mytilus galloprovincialis populations. Molecular Marine Biology and Biotechnology, 3, 334-337.

Gold JR, Richardson LR (1998) Mitochondrial DNA diversification and population structure in fishes from the Gulf of Mexico and western Atlantic. Journal of Heredity, 89, 404-414.

Gopurenko D, Hughes JM, Keenan CP (1999) Mitochondrial DNA evidence for rapid colonization of the Indo-West Pacific by the mudcrab Scylla serrata. Marine Biology, 134, 227-233.

Grosberg R, Cunningham CW (2001) Genetic structure in the sea from populations to communities. In: Marine Community Ecology (eds Bertness MD, Gaines SD, Hay ME), pp. 61-84. Sinauer Associates Inc., Sunderland, MA.

Gurgel CFD, Fredericq S, Norris JN (2004) Phylogeography of Gracilaria tikvahiae (Gracilariaceae, Rhodophyta): a study of a genetic discontinuity in a continuously distributed species based on molecular evidence. Journal of Phycology, 40, 748-758.

Hare MP, Avise JC (1996) Molecular genetic analysis of a stepped multilocus cline in the American oyster (Crassostrea virginica). Evolution, 50, 2305-2315.

Hare MP, Avise JC (1998) Population structure in the American oyster as inferred by nuclear gene genealogies. Molecular Biology and Evolution, 15, 119-128.

Hare MP, Karl SA, Avise JC (1996) Anonymous nuclear DNA markers in the American oyster and their implications for the heterozygote deficiency phenomenon in marine bivalves. Molecular Biology and Evolution, 13, 334-345.

Hillis DM, Mable BK, Moritz C (1996) Applications of molecular systematics. In: Molecular Systematics (eds Hillis DM, Moritz C, Mable BK), pp. 515-530. Sinauer Associates, Sunderland, MA.

Hoeh WR, Blakley KH, Brown WM (1991) Heteroplasmy suggests limited biparental inheritance of Mytilus mitochondrial DNA. Science, 251, 1488-1490.

Hoeh WR, Stewart DT, Sutherland BW, Saavedra C, Zouros E (1997) Phylogenetic evidence for role-reversals of genderassociated mitochondrial DNA in Mytilus. Molecular Biology and Evolution, 14, 959-967.

Iturralde-Vinent MA, MacPhee RDE (1999) Paleogeography of the Caribbean region: implications for Cenozoic biogeography. Bulletin of the American Museum of Natural History, 283, 1-95.

Karl SA, Avise JC (1992) Balancing selection at allozyme loci in oysters: implications from nuclear RFLPs. Science, 256, 100-102.

Kirkendale L, Lee T, Baker PÓ, Foighil D (2004) Oysters of the Conch Republic (Florida Keys); a molecular phylogenetic study of Parahyotissa mcgintyi, Teskeyostrea weberi and Ostreola equestris. Malacologia, 46 , in press.

Knowlton N (1993) Sibling species in the sea. Annual Review of Ecology and Systematics, 24, 189-216.

Knowlton N (2000) Molecular genetic analyses of species boundaries in the sea. Hydrobiologia, 420, 73-90.

Kohn AJ, Perron FE (1994) Life History and Biogeography Patterns in Conus. Oxford Biogeography Series 9. Clarendon Press, Oxford.

Kuhner MK, Yamato J, Felsenstein J (1998) Maximum likelihood estimation of population growth rates based on the coalescent. Genetics, 149, 429-434.

Lavery S, Moritz C, Fielder DR (1996) Genetic patterns suggest exponential population growth in a declining species. Molecular Biology and Evolution, 13, 1106-1113.

Lee T, Ó Foighil D (2003) Phylogenetic structure of the Sphaeriinae, a global clade of freshwater bivalve molluscs, inferred from 
nuclear (ITS-1) and mitochondrial (16S) ribosomal gene sequences. Zoological Journal of the Linnean Society, 137, 245-260.

Lessios HA, Kessing BD, Robertson DR (1998) Massive gene flow across the world's most potent marine biogeographic barrier. Proceedings of the Royal Society London Series B, 265, 583-588.

Lessios HA, Kessing BD, Robertson DR, Paulay G (1999) Phylogeography of the pantropical sea urchin Eucidaris in relation to land barriers and ocean currents. Evolution, 53, 806-817.

Liu HP, Mitton JB, Wu SK (1996) Paternal mitochondrial DNA differentiation far exceeds maternal mitochondrial DNA and allozyme differentiation in the freshwater mussel, Anodonta grandis grandis. Evolution, 50, 952-957.

Marko PB (2002) Fossil calibration of molecular clocks and the divergence times of geminate species pairs separated by the Isthmus of Panama. Molecular Biology and Evolution, 19, 20052021.

Marshall LG (1988) Land mammals and the Great American Interchange. American Scientist, 76, 380-388.

McDonald JH, Verrelli BC, Geyer LB (1996) Lack of geographic variation in anonymous nuclear polymorphisms in the American oyster, Crassostrea virginica. Molecular Biology and Evolution, 13, 1114-1118.

Mikkelsen PM, Bieler R (2000) Marine bivalves of the Florida Keys: discovered biodiversity. In: The Evolutionary Biology of the Bivalvia (eds Harper EM, Taylor JD, Crame JA), Geological Society of London. Special Publications, 177, 367-387.

Morton B (1988) The population dynamics and reproductive cycle of Brachidontes variabilis (Bivalvia: Mytilidae) in a Hong Kong mangrove. Malacological Review, 21, 109-117.

Nei M (1987) Molecular Evolutionary Genetics. Columbia University Press, New York, NY.

Nei M, Li W-H (1979) Mathematical model for studying genetic variation in terms of restriction endonuclease. Proceedings of the National Academy of Sciences of the USA, 76, 5269-5273.

Neigel JE, Avise JC (1986) Phylogenetic relationships of mitochondrial DNA under various demographic models of speciation. In: Evolutionary Processes and Theory (eds Nevo E, Karlin S), pp. 515-534. Academic Press, New York, NY.

Palumbi SR (1992) Speciation on a small planet. Trends in Ecology and Evolution, 7, 114-118.

Palumbi SR (1994) Genetic divergence, reproductive isolation, and marine speciation. Annual Review of Ecology and Systematics, 25, 547-572.

Park J-K, Ó Foighil D (2000) Sphaeriid and corbiculid clams represent separate heterodont bivalve radiations into freshwater environments. Molecular Phylogenetics and Evolution, 14, 75-88.

Passamonti M, Boore JL, Scali V (2003) Molecular evolution and recombination in gender-associated mitochondrial DNAs of the Manila clam Tapes philippinarum. Genetics, 164, 603-611.

Pielou EC (1991) After the Ice Age. University of Chicago Press, Chicago, IL.

Posada D, Crandall KA (1998) modeltest: testing the model of DNA substitution. Bioinformatics, 14, 817-818.

Posada D, Crandall KA (2001) Selecting models of nucleotide substitution: An application to human immunodeficiency virus 1 (HIV-1). Molecular Biology and Evolution, 18, 897-906.

Quesada H, Skibinski DAG, Skibinski DOF (1996) Sex-biased heteroplasmy and mitochondrial DNA inheritance in the mussel Mytilus galloprovincialis Lmk. Current Genetics, 29, 423-426.

Quesada H, Stuckas H, Skibinski DOF (2003) Heteroplasmy suggests paternal co-transmission of multiple genomes and pervasive reversion of maternally into paternally transmitted genomes of mussel (Mytilus) mitochondrial DNA. Journal of Molecular Evolution, 57, S138-S147.

Randazzo AF, Jones DS (1997) The Geology of Florida. University Press of Florida, Gainesville, FL.

Rawson PD, Hilbish. TJ (1995) Evolutionary relationships among the male and female mitochondrial DNA lineages in the Mytilus edulis species complex. Molecular Biology and Evolution, 12, 893 901.

Reeb CA, Avise JC (1990) A genetic discontinuity in a continuously distributed species: mitochondrial DNA in the American oyster, Crassostrea virginica. Genetics, 124, 397-406.

Ronquist F, Huelsenbeck JP (2003) MRBAYEs 3: Bayesian phylogenetic inference under mixed models. Bioinformatics, 19, 1572-1574.

Sarver SK, Landrum MC, Foltz DW (1992) Genetics and taxonomy of ribbed mussels (Geukensia spp.). Marine Biology, 113, 385-390.

Saunders NC, Kessler LG, Avise JC (1986) Genetic variation and geographic differentiation in mitochondrial DNA of the horseshoe crab, Limulus polyphemus. Genetics, 112, 613-627.

Schizas NV, Street GT, Coul BC, Chandler GT, Quattro JM (1999) Molecular population structure of the marine benthic copepod Microarthridion littorale along the southeastern and Gulf coasts of the USA. Marine Biology, 135, 399-405.

Schneider S, Roessli D, Excoffier L (2000) ARLEQUIN: a Software for Population Genetics Data Analysis, Version 2.000. Genetics and Biometry Laboratory, University of Geneva, Switzerland.

Skibinski DOF, Gallagher C, Benyon CM (1994) Mitochondrial DNA inheritance. Nature, 368, 817-818.

Skibinski DOF, Gallagher C, Quesada H (1999) On the roles of selection, mutation and drift in the evolution of mitochondrial DNA diversity in British Mytilus edulis (Mytilidae; Mollusca) populations. Biology Journal of the Linnean Society, 68, 195-213.

Sterrer W (1986) Marine Fauna and Flora of Bermuda. Wiley and Sons, New York, NY.

Stewart DT, Saavedra C, Stanwood RR, Ball AO, Zouros E (1995) Male and female mitochondrial DNA lineages in the blue mussel (Mytilus edulis) species group. Molecular Biology and Evolution, 12, 735-747.

Swofford DL (2003) PAUP*: Phylogenetic Analysis Using Parsimony ( ${ }^{*}$ and Other Methods), Version 4. Sinauer Associates, Sunderland, MA.

Tajima F (1983) Evolutionary relationship of DNA sequences in finite populations. Genetics, 105, 437-460.

Tajima F (1989) Statistical method for testing the neutral mutation hypothesis by DNA polymorphism. Genetics, 123, 585-595.

Tamura K, Nei M (1993) Estimation of the number of nucleotide substitution in the control region of mitochondrial DNA in humans and chimpanzees. Molecular Biology and Evolution, 10, 512-526.

Templeton AR, Crandall KA, Sing CF (1992) A cladistic analysis of phenotypic associations with haplotypes inferred from restriction endonuclease mapping and DNA sequence data. III. Cladogram estimation. Genetics, 132, 619-633.

Thompson JD, Gibson TJ, Plewniak F, Jeanmougin F, Higgins DG (1997) The CLUSTAL_x window interface: flexible strategies for multiple sequence alignment aided by quality analysis tools. Nucleic Acids Research, 25, 4876-4882.

Wares JP (2002) Community genetics in the northwestern Atlantic intertidal. Molecular Ecology, 11, 1131-1144.

Wares JP, Cunningham CW (2001) Phylogeography and historical ecology of the North Atlantic intertidal. Evolution, 55, 2455-2469.

Webb SD (1990) Historical biogeography. In: Ecosystems of Florida (eds Myers RI, Ewel JJ), pp. 70-100. University of Central Florida Press, Orlando, FL. 
3542 T. LEE and D. Ó FOIGHIL

White LR, McPherson BA, Stauffer JR (1996) Molecular genetic identification tools for the unionids of French Creek, Pennsylvania. Malacologia, 38, 181-202.

Williams ST, Benzie JAH (1998) Evidence of a biogeographic break between populations of a high dispersal starfish: congruent regions within the Indo-West Pacific defined by color morphs, mtDNA, and allozyme data. Evolution, 52, 87-99.

Williams D, Dunkerley D, DeDekker P, Kershaw P, Chappel M (1998) Quaternary Environments. Arnold, London.

Xu Z, Guo X, Gaffney PM, Pierce JC (2001) Chromosomal location of the major ribosomal RNA genes in Crassostrea virginica and Crassostrea gigas. Veliger, 44, 79-83.
Zouros E, Ball AO, Saaverda C, Freeman KR (1994) Mitochondrial DNA inheritance. Nature, 368, 818.

Taehwan Lee and Diarmaid Ó. Foighil both share interests in molluscan systematics and evolution and work on marine, freshwater and terrestrial taxa. Lee (http://www.ummz.lsa.umich.edu/mollusks/ people/taehwan.html) is currently an NSF postdoctoral fellow and Ó Foighil (http://www.ummz.lsa.umich.edu/mollusks/people/ diarmaid.html) is an associate Curator of Malacology at the University of Michigan Museum of Zoology. 